\title{
БРАЧНЫЕ ЗАКОНЫ КАК ИНСТРУМЕНТ УКРЕПЛЕНИЯ РИМСКОГО ГОСУДАРСТВА В ПРАВЛЕНИЕ ОКТАВИАНА АВГУСТА
}

\author{
А. А. Инков \\ Московский гуманитарный университет
}

Аннотация: В статье рассматриваются особенности брачно-семейного законодательства римского императора Октавиана Августа. Анализируются причины введения брачных законов, их особенности, прослеживается влияние законодательства в области семьи и брака на различные сословия римского общества.

Ключевые слова: брачные законы; Римское государство; Август; империя; высшие сословия; римская семья

\section{MARRIAGE LAWS AS A TOOL TO STRENGTHEN THE ROMAN STATE DURING THE REIGN OF OCTAVIAN AUGUSTUS}

\author{
A. A. Inkov \\ Moscow University for the Humanities
}

Abstract: The article considers the peculiarities of marriage and family law of the Roman emperor Octavian Augustus. The author analyzes the reasons for the introduction of marriage laws and their features; he follows the influence of legislation in the field of family and marriage on various strata of Roman society.

Keywords: marriage laws; Roman state; Augustus; empire; upper classes; Roman family

Гражданские войны 40-30-х гг. I в. до н. э. открывают новый период римской истории, когда на смену поздней Республике в Риме утверждается новая политическая система - монархия (так называемый принципат, от лат. princeps - «первый») во главе с пасынком Юлия Цезаря Октавианом Августом. Однако победа Октавиана над соперниками и окончание гражданских войн еще не означали стабильности установленного с приходом монархии нового политического порядка.

В целях укрепления монархии в период своего правления Августом были проведены широкие реформы, затронувшие различные стороны экономической, социально-политической, военной и культурной жизни римского общества. Внешне большинство этих реформ осуществлялось под 
лозунгом восстановления республиканских порядков, возврата к обычаям предков, моральным и религиозным основам старого римского общества, разрушенным в результате полосы непрерывных политических катаклизмов прежнего времени (см. подр.: Cambridge Ancient History, 2008; Сергеев, 1938; Levy, 1951; Ковалев, 1986; Дмитриенко, 2004; Фереро, 1998; Машкин, 1949; Крист, 1997; Шифман, 1990 и др.). Однако если восстановление старины было внешней стороной реставрационной политики Августа, ее внутренняя сторона была неразрывно связана с укреплением монархии, созданием прочного фундамента для ее дальнейшего развития.

Несмотря на то, что Август стремился создать максимально широкую опору своей власти и с этой целью проводил внутреннюю политику в интересах всех слоев римского общества, основным объектом его внимания выступали прежде всего высшие сословия римской знати: сенаторы и всадничество (Galinsky, 1981; Межерицкий, 1994: 226). Это было далеко не случайным. В руках высших сословий были сосредоточены все важнейшие функции управления государством: они занимали ключевые места в экономике, составляли чиновничий аппарат столицы и провинций, отправляли судопроизводство, заведовали религиозными общегосударственными культами и т. д. Из представителей знати почти исключительно состоял высший состав римской армии. Поэтому пришедшая на смену республике монархия во главе с Августом создавалась в значительной степени путем интеграции в ее структуры прежних экономических и политических систем республики, вследствие чего, несмотря на ограничение возможности староримской знати влиять на принятие решений по управлению государством, высшие сословия по-прежнему продолжали играть важную роль и при новом режиме. Их лояльность и поддержка существующего строя были важнейшим условием его функционирования. Вследствие этого внутренняя политика Августа была направлена как на обеспечение лояльности высших сословий новому порядку, так и преследовала целью поставить их опыт, силы и знания на службу империи (Кузищин, 2000: 193-194).

Очевидно, что простое привлечение римской знати на службу нарождающейся монархии было далеко не основной целью реставрационной политики Августа. Август ставил более широкие задачи. Важнейшая из них заключалась в придании новому режиму такого блеска и величия, при которых в обществе, еще сохранявшем остатки прежней республиканской ненависти к царям, должно было сложиться мнение, что с приходом диктатуры Августа Римское государство вступило в эпоху «золотого века», освященного высшими богами, а сама империя, принесшая с собой римлянам после десятилетий усобиц и войн мир и стабильность, гораздо выгоднее обществу, чем дискредитировавшая себя республика (Вергилий, 1971: 239; 
Научные труды Московского гуманитарного университета 2019 № 2

Гораций, 1936: 173-174; Овидий, 1990: 82; Токарев, 2004; 229-230). Решение этой важной задачи требовало от Августа предъявления повышенных требований как к себе, так и к тем представителям различных слоев римского общества, прежде всего староримской знати, которые вербовались на службу новому порядку.

Однако здесь-то и заключались непреодолимые трудности. Разложение поздней Республики, начавшееся еще в последние десятилетия II в. до н. э. затронуло высшие сословия в большей степени, чем остальные слои римского общества. Сенаторская знать, стоявшая в течение нескольких столетий во главе республики, с разгромом основных внешних врагов Рима в бассейне Средиземного моря, обратила все силы внутрь себя и всю вторую половину II - середину I в. до н. э. активно боролась между собой за власть в государстве. Непрерывная борьба этих группировок за власть в стране, в которую в той или иной степени были втянуты все слои римского общества и в которой для победы все средства были хороши, оказала свое негативное влияние не только на процессы социально-экономического и политического развития Римского государства, но и привела к смене многих моральных установок общества. В ходе этой борьбы на передний план выдвинулись такие качества, как изворотливость, продажность, предательство, измена (Шифман, 1990: 116). Не последнюю роль в этом процессе, безусловно, играло и превращение Рима на рубеже II-I вв. до н. э. из города-государства в мировую державу, охватившую весь бассейн Средиземного моря. С захватом римлянами богатейших стран Востока и Африки в Италию хлынул поток богатств, а вслед за этим и религиозные культы, расшатывавшие фамильные связи и традиционную римскую мораль (Егер, 1997: 662). Полисная мораль Рима, основанная на таких устоях, по крайней мере, теоретических, римской жизни как «fides» - «верность», «pietas» - «благочестие», «virtus» - «мужество», которые исконно должны были быть присущи доброму римлянину старого закала, в новых экономических и политических условиях развития римского общества была безжалостно разрушена (Чаплыгина, 1995: 108).

Отрицание традиционной нравственности, переставшей в новых условиях отвечать реалиям жизни при отсутствии каких бы то ни было моральных альтернатив, имело своим следствием распространение в различных слоях римского общества такого явления, как моральный индиффертизм моральный вакуум (Брейкин, 1992: 94). Нестабильность экономической и политической жизни, когда в условиях гражданских войн, сопровождавшихся массовой резней римских граждан, непрерывными казнями и преследованиями неугодных, человек не знал, что его может ожидать завтра и жил только сегодняшним днем, приводила к разрыву всех прежних его фамильных связей, обеспечивавших преемственность поколений, разрушала 
его связь с невидимым миром предков, выступавшим духовным стержнем жизни любого римлянина. В этих условиях такие понятия как брак и семья перестали рассматриваться как краеугольные понятия нравственного римского сознания. Следствием этого было крушение всей системы нравственных ценностей римского общества. Состоятельные римляне все меньше хотели связывать себя семьей (Тацит, 2001: 117), так как считали ее как обременительную и опасную обузу и стремились либо совсем не вступать в брак, либо рассматривали последний как кратковременный и ничего не значащий акт, который в любой момент может быть расторгнут. В І в. до н. э. безбрачие, бездетные браки и большое число разводов становятся в среде римского правящего слоя массовым явлением (Крист, 1997: 135).

Нельзя сказать, что моральный вакуум высших сословий ничем не был заполнен. Протестуя против мрачной действительности, римляне искали успокоения в сферах, традиционно вызывавших осуждение в обществе. К началу правления Августа (27 г. до н. э.) проституция и ужасающая распущенность нравов достигают в Риме огромных масштабов. Характерно, что носителем всех этих пороков была во многом именно столичная знать, которая, оказавшись отчужденной от государственных дел и привыкнув к этому, все чаще пренебрегала выполнением своего государственного, религиозного и семейного долга. Так, в 12 г. до н. э. из-за отсутствия желающих сорвались выборы народных трибунов, и Августу пришлось искать кандидатов из всадников (Кассий Дион, 2014: 208). В 5 г. до н. э. ситуация повторилась, на этот раз при выборе эдилов, и их пришлось выбрать из квесторов и народных трибунов (там же: 263). Эти и другие угрожающие тенденции не могли не вызвать серьезного беспокойства Августа, для которого высшие сословия были главной опорой его власти.

Преодоление негативных тенденций общественного развития виделось Августу и его окружению в укреплении прежних древних моральных и религиозных устоев римского civitas (Csillag, 1976: 138). Характерно, что избавление от моральной деградации общества связывалось с именем императора и передовыми мыслителями того времени. В своих воззваниях к Августу они требовали от него восстановить мир и традиционные отношения (Гораций, 1936: 173-174). Под последними, очевидно, понималось восстановление прошлого, всего того, что римляне называли mairoum — «обычаями предков» (Чаплыгина, 1995:108). Поэтому характерным лозунгом внутренней политики Августа, как и всего комплекса его реставрационных мер, было возвращение к старине.

Главное направление этой политики занимала борьба с ужасающей распущенностью нравов и укрепление древнеримской семьи. Преодолеть негативные процессы общественного развития было призвано брачно-се- 
Научные труды Московского гуманитарного университета 2019 № 2

мейное законодательство Августа, наиболее интенсивно развивавшееся в промежуток между 18 г. до н. э. и 9 г. н. э. В 18 г. до н. э. в целях ограничения безбрачия, которое все более и более начинало преобладать среди знати, и упорядочивания семейной жизни была издана серия законов, которые принято объединять в две группы или даже два закона. Оба эти закона получили в исторической науке название Юлиевых. Первый из них, Lex Iulia de maritandis ordinibus (закон, ограничивающий браки между различными сословиями) был направлен на укрепление традиционной римской семьи и увеличение воспроизводства населения. Второй закон (серия законов) «Юлиев закон о прелюбодеяниях» (Lex Iulia de adulteriis coercendis) касался борьбы с ужасающей распущенностью нравов и возрастающей безнравственностью взаимоотношений между полами.

Первые попытки регулирования брачно-семейных отношений предпринимались еще в период гражданских войн. Однако, в условиях борьбы за власть они носили больше рекламный характер, чем реально были направлены на решение острых социальных проблем. После окончания египетского похода в 28 г. до н. э. Августом была предпринята попытка ввести закон об обязательных браках, однако по неизвестным причинам вскоре этот закон был отменен (Шифман, 1990: 116). В 18 г. до н. э. с началом широкого вмешательства государства в сферу брачно-семейных отношений закон о браках был восстановлен. Объектом его воздействия стали лица сенаторского и всаднического сословий (Ульпиан, 1998: 189). Чтобы положить конец безбрачию высших сословий закон обязал всех мужчин в возрасте от 25 до 60 лет и женщин от 20 до 50 лет вступить в брак (Ульпиан, 1998: 187; Betzig, 1992: 346. В случае прекращения брака со смертью одного из супругов или после развода граждане должны были заключить повторный брак. Одновременно, чтобы сохранить «чистоту» римской крови, сенаторам было запрещено вступать в брак с дочерьми вольноотпущенников и актрисами, стоявшими в римском обществе на самых низших ступенях социальной лестницы, а римским гражданам - с проститутками и нарушительницами супружеской верности и прочими дискредитировавшими себя женщинами. За нарушение закона полагались суровые наказания. Так, граждане, не вступившие в брак, были лишены права присутствовать на зрелищах. C ослаблением роли народного собрания во времена императоров цирк служил не только развлечением народа, но и являлся местом обсуждения римлянами важнейших вопросов внутренней и внешней политики Римского государства, а также встреч народа с императором. Запрет гражданам, не вступившим в брак, присутствовать на зрелищах устранял римлян от участия в важнейшей сфере жизнедеятельности общины, связанной с решением ее важнейших проблем, и тем самым фактически лишал их части гражданских 
прав. Это наказание в какой-то степени, очевидно, распространялось и на про-стой народ, против которого действие закона о браках не было направлено напрямую. По словам Светония, Август приказал разделить трибуны в цирке на три части: одну для людей женатых, вторую - для несовершеннолетних, и третью - для их наставников (Светоний, 1990: 56). Можно предполагать, что эта мера также была призвана каким-то образом стимулировать простой народ к заключению браков.

Вместе с тем, закон о браках предусматривал и более суровые наказания за отказ римлян вступать в брак, чем просто лишение права присутствовать в цирке. Лица, не вступившие в брак и не имевшие семью, по закону подлежали ограничению также в своих завещательных правах. Они были лишены права получать наследство по завещанию, которое целиком отходило в государственную казну. Это наносило мощный удар по материальному положению римской знати, сосредоточившей в своих руках огромные богатства и чувствовавшей себя экономически независимой от центральной власти. Ограничение завещательных прав сенаторов и всадников не только давало в руки правительства мощные рычаги экономического воздействия на знать, но и, по-видимому, было напрямую экономически выгодно государству, которое таким образом получало важный источник пополнения казны. Как и в отношении отказывавшихся вступать в брак, эта мера в полной мере распространялась и на семьи, не имевшие детей.

В меньшей степени закон о браках затрагивал положение римской женщины. Несмотря на то, что он предписывал всем римлянкам в возрасте от 20 до 50 лет вступать в брак, наказание к его нарушительницам было достаточно мягким и ограничивалось лишь взиманием в пользу государства налога в размере $1 \%$ со всего их имущества. Очевидно, в данном случае сказывалось традиционное уважение в римском обществе к женщине, которая к концу I в. до н. э. достигла в своем положении значительной правовой и экономической свободы, ограничить которую, несмотря на беспощадную борьбу с безбрачием и распущенностью нравов, Август не решился.

В том же 18 г. до н. э., Августом был принят закон о запрете прелюбодеяний (Lex Iulia de adulteriis coercendis). Как и закон об ограничении браков, он был призван урегулировать семейные отношения внутри римской знати. Однако в отличие от первого закона, закон о запрете прелюбодеяний носил более карательный характер и был призван укрепить семейные узы прежде всего за счет повышения ответственности отца и мужа за поведение дочери и жены. За супружескую измену и занятие проституцией вводились суровые наказания. Женщина, уличенная в прелюбодеянии, немедленно получала развод со стороны своего мужа и отдавалась под суд, причем отец имел право убить свою дочь и ее любовника, а муж - убить любовника, если он 
Научные труды Московского гуманитарного университета 2019 № 2

не был свободнорожденным: рабом, вольноотпущенником семьи, гладиатором, артистом и т. д. (Дигесты, 2005: 48; Treggiari, 1991: 293). Эти наказания, естественно, также относились и к мужчинам, уличенным во внебрачных связях (Дигесты, 2005: 48; Юлий Павел, 1996: 49).

Особую жестокость закону о прелюбодеяниях придавало то, что все дела об адюльтере должны были предаваться огласке и рассматри-ваться в государственных судах наряду с особо опасными преступлениями (Юлий Павел, 1996: 49). В связи с этим, закон прямо обязывал отца или мужа привлекать женщину к суду. В случае, если в течение полугода после совершенного преступления отец или муж не привлекали уличенную в преступлении женщину к суду, они могли быть сами отданы под суд в качестве сводников (там же: 39-41).

Таким образом, Юлиевы законы были призваны укрепить римскую семью и вернуть отношения между ее членами к традиционным устоям. Законодательство Августа вводило целый набор карательных мер к нарушителям супружеской верности, обязывало всех граждан вступать в брак и рожать детей. Однако как показали последующие события, издание брачных законов оказалось не только не способным эффективно противостоять негативным процессам развития общества, но и значительно обострило кризис древнеримской семьи. Семья издревле была сферой общественных отношений, в которой власть государства всегда стояла ниже власти главы семейства. Последний рассматривался как единственный господин над своими домочадцами, в решения которого (право убить или миловать) государство по законам XII таблиц не могло вмешиваться или могло вмешиваться лишь в ограниченной степени (Новицкий, 1998: 63-68). С принятием Юлиевым законов, грубое, бесцеремонное вмешательство властей в сферу семейных отношений ослабляло власть отца или мужа в семье, подрывало его положение и вело к разрыву традиционных отношений между членами семьи, которые могли теперь напрямую обращаться к императору с просьбой решить их проблемы или ограничить власть домовладыки. Это не могло не вызвать недовольства и сопротивления римлян, которые расценивали стремление государства поставить под свой контроль семью как вмешательство властей в их личную жизнь, ограничение их исконных прав и свобод.

Одними административными мерами невозможно было решить весь комплекс проблем, копившихся в римском обществе десятилетиями. Невозможно было укрепить семью, указывая человеку, когда ему жениться, сколько рожать детей, или с помощью законов пытаться изменить его образ жизни. Законодательство Августа не учитывало, что кризис брачно-семейных отношений в римском обществе был вызван вовсе не граждански- 
ми войнами, которые его только обострили, а прежде всего трансформацией самой модели римского полиса, который давно превратился из общины равноправных граждан, в равной мере принимавших участие в ее управлении и разделявших ответственность за ее жизнедеятельность, в общество, в котором верховная власть все больше сосредотачивалась в руках относительно узкой группы граждан, оттеснивших от управления государством подавляющее большинство остальных граждан. Нарушение общественных функций гражданского коллектива вело к распространению в его среде абсен-теизма, справиться с которым даже самые лучшие законы были не в состоянии. Несоответствие Юлиевых законов объективной реальности показывает известный стих римского поэта Горация: «Что нам законы, когда они не находят себе опоры в нравах!» Отрицательные последствия брачных законов Августа подчеркивал позднее и Тацит, оценивавший законы об адюльтере как излишне идеологизированные и суровые, а тем самым противоречащие древнему милосердию (Тацит, 2001: 116).

Характерно, что Август, активно призывавший к возврату к временам староримской строгости, далеко сам не был образцом для подражания. В обществе хорошо были известны его многочисленные любовные похождения. Не все было благополучно и в самой семье Августа. Чтобы жениться на своей третьей супруге Ливии Друзилле, Август силой отнял ее у мужа Тиберия Нерона, хотя она и ждала от него ребенка (Светоний, 1990: 62). Дочь Августа Юлия Старшая и его внучка Юлия Младшая настолько запятнали себя развратом, что престарелый император был вынужден удалить обеих в ссылку, где они впоследствии и умерли (там же: 63).

Несмотря на активное проведение правительством Августа в жизнь Юлиевых законов, они так и не достигли своей цели. Законы не пользовались популярностью в среде римской знати, которая хотя открыто и не выступала против, но и не поддерживала их. Когда Август собирался сделать закон о браках еще более строгим, всадники обратились к императору с просьбой отменить непопулярный закон (Светоний, 1990: 52). Подспудное общественное недовольство законами о браках проявилось в поэме Публия Овидия Назона «Об искусстве любви», в которой поэт высмеял тщетность усилий правительства по нравственному оздоровлению римлян (Шифман, 1990: 116). В итоге, в 8 г. н. э. Назон был сослан Августом на окраину империи в причерноморский город Томы, где вскоре умер, однако эта жестокая расправа также не помогла изменить общего негативного отношения к брачно-семейным законам Августа.

Более того, римская знать быстро научилась находить многочисленные лазейки в несовершенном законодательстве для обхода законов. Одним из таких способов стало заключение фиктивных браков (Ковалев, 1986: 484). 
Научные труды Московского гуманитарного университета

2019 № 2

Неэффективность Юлиевых законов по исправлению негативных процессов общественного развития с новой силой проявилась в 9 г. н. э. во время восстания покоренных римлянами германских племен во главе с Ариовистом. На подавление этого мятежа были брошены римские войска во главе с наместником провинции Германия Квинтилием Варом, однако восставшие уничтожили их вместе с военачальником (Веллей Патеркул, 1996: 89; Mcnally, 2011). Это поражение привело к отпадению от Рима всех прежде завоеванных германских владений и создало опасность прорыва варварами границы. В Риме ожидали вторжения германцев в Италию. Правительство принимало срочные меры к его отражению. По приказу Августа, был объявлен набор в войско, однако римляне, против ожидания, не проявили желания записаться в солдаты, а многие открыто уклонились от службы. Подобное пренебрежение исполнением воинского долга было неслыханным в истории Рима. В итоге, Август вынужден был прибегнуть к решительным мерам: некоторые из отказавшихся вступить в армию были казнены, среди других была проведена жеребьевка и каждый пятый из тех, кто был младше 35 лет, и каждый десятый из тех, кто были старше, были лишены гражданских прав и имущества (Шифман, 1990: 119-120).

Однако было ясно, что все предшествующие попытки Августа вер-нуть в общество чистоту нравов и былые доблести потерпели неудачу. Обеспокоенность правительства вызывал тот факт, что у государства уже не хватало достаточного количества солдат для ведения войн, что напрямую затрагивало важнейшую сферу интересов монархии - армию, являвшуюся главной опорой режима Августа (Штаерман, 1956: 28-31). Проблема нехватки людей для армии порождала у правительства стремление к созданию условий для увеличения воспроизводства римских граждан, и это подтолкнуло Августа к необходимости издания новых семейных законов. Довольно трудно определить, было ли вызвано принятие этих законов ухудшением условий комплектования римской армии добровольцами, наиболее остро проявившееся в период восстания Ариовиста, или обеспокоенностью государства нежеланием граждан Рима в принципе идти на военную службу (Galinsky, 1981: 127). Тем не менее, сам факт нового вмешательства государства в сферу семейных отношений, причем теперь оно попыталось взять на себя контроль над важнейшей функцией семьи - процессом воспроизводства, свидетельствовал о продолжавшихся безуспешных попытках монархии регламентировать и эту сторону семейной жизни общества.

Следует заметить, что воспроизводство римской знати на протяже-нии всей истории Рима оставалось крайне низким (Hopkins, 1983: 78). Многие патрицианские роды постоянно находились на грани вымирания, вследствие чего дети, родившиеся в одной семье, рассматривались в римском 
праве как «собственность» всей гражданской общины, а не отдельных семей. Поэтому роды, не способные к собственному воспроизводству, могли обеспечить свое дальнейшее существование, применяя право т. н. «покупки» детей, путем усыновления или удочерения детей из семьи, в которой было большое потомство, в семью, его не имевшую. Тем самым обеспечивалось фактическое существование всех римских родов, игравших активную роль в управлении государством, вне зависимости от их репродуктивных возможностей. С установлением монархии, когда высшие сословия стали рассматриваться как служилые сословия, призванные отдавать свои знания и опыт на службу новому порядку, государство вынуж-денно было взять на себя заботу об их воспроизводстве. Пополнение и увеличение числа знати становится важнейшим условием функционирования всего административно-чиновничьего аппарата империи.

В итоге в 9 г. н. э. в дополнение к Юлиевым законам был принят новый закон, получивший название закона Папея и Поппея (Lex Papia Poppaea). Его авторами были сенаторы Папей и Поппей, ближайшие сподвижники императора, однако вряд ли разработка закона обошлась без непосредственного участия самого Августа. Закон Папея и Поппея сохранял общее направление политики властей на укрепление семьи, но в то же время значительно смягчал условия вступления в брак и отменял некоторые карательные меры за нарушение законов о браках. По словам Светония, причина этих уступок заключалась в неэффективности закона о браках. «Узнав, что некоторые обходят закон, обручаясь с несовершеннолетними или часто меняя жен ...», Август в новом законе «сократил срок помолвки и ограничил разводы» (Светоний, 1990: 52). В частности, если Юлиев закон обязывал римлян вступать в новый брак через год после вдовства и через полгода после развода, то теперь закон Папея и Поппея увеличивал этот срок до двух лет и восемнадцати месяцев, соответственно (Treggiari, 1991: 73; Бэлсдон, 2016: 96). Значительно были ограничены возможности вступления в брак с несовершеннолетними. Отныне по закону невеста должна была быть не моложе 10 лет, период ее обручения не мог продолжаться свыше 12 лет. Одновременно с этим, число разводов было ограничено до трех (Гребенюк, 1994: 174).

Важные изменения новым законом вносились также в порядок наследования имущества бездетными и холостяками. Эти категории граждан были отделены друг от друга. Холостяки по-прежнему были лишены права наследовать имущество. Приравненные к ним по Юлиеву закону бездетные, но состоявшие в браке граждане, напротив, теперь получили право на наследование половины наследства. Со стороны государства это было вынужденной уступкой имущим слоям населения, которая имела целью снискать популярность проводимой Августом социальной политики. Однако в 
Научные труды Московского гуманитарного университета 2019 № 2

этом же проявлялась и ее непоследовательность.

Основное содержание закона Папия и Поппея сводилось к вопросам регулирования воспроизводства населения. Чтобы стимулировать граждан к заключению браков и увеличить деторождение, законом вводилась гибкая система привилегий, с одной стороны, и увеличение штрафов, с другой. С этой целью в римское право вводилось понятие права трех детей, т. н. ius trium liberorum. Обладателями этого права по новому закону становились представители знати, имевшие трех и более детей. Закон закреплял в их отношении освобождение от всех законодательных мер. Сенаторы и всадники наделялись рядом крупных привилегий и льгот: отец семейства, имеющий трех и более детей, получал преимущество перед бездетным при занятии государственных должностей (Тацит, 2001: 83) и т. д.

Закон Папия и Поппея значительно расширил права женщин, в том числе имущественные. Женщина, родившая трех детей, в отношении своих клиентов наделялась такими же правами, как и патрон. Ей разрешалось носить особое почетное платье - особо украшенную столу (род женской одежды), которое давало право на титул «носительницы семейной столы» (stolata femina). Мать трех детей после смерти супруга освобождалась от опеки со стороны своего рода, т. е. получала полную экономическую и юридическую свободу.

Наряду с некоторыми послаблениями новый закон усиливал карательные меры к нарушителям семейных законов (Csilag, 1976: 32). Помимо многочисленных штрафов, он устанавливал награды доносчикам, т. е. фактически стимулировал доносительство на тех, кто уклонялся от исполнения супружеских обязанностей. Доносить на своих хозяев разрешалось даже домашним рабам. Раб, донесший об аморальном поведении своего хозяина, поощрялся денежным вознаграждением и даже мог быть отпущен на свободу в случае конфискации имущества владельца (Гребенюк, 1994: 174).

Тем не менее, несмотря на значительные усилия правительства по совершенствованию семейного законодательства, закон Папия и Поппея не изменил общей ситуации в области брачно-семейных отношений. Так же, как и предыдущие Юлиевы законы, он содержал в себе много противоречий, в которых проявлялась непоследовательность самой семейной политики Августа. К примеру, авторы этого закона - сенаторы Папий и Поппей - сами были не женатыми (Межерицкий, 1994: 243). Кроме того, ни сам Август, ни его жена Ливия также не подпадали под действие этого закона (Крист, 1997: 136). Поэтому так же, как и первые брачные законы, закон Папия и Поппея, продолжавший практику вмешательства государства в личную жизнь граждан, не встретил поддержки населения. По словам Тацита, в результате введения этих законов «супружества не стали от этого чаще и детей не ро- 
ждалось больше, так как против желания оставаться бездетными эта мера оказалась бессильной» (Тацит, 2001: 117). Правда, следует отметить, что по данным двух цензов 28 г. до н. э. и 13 г. н. э. число римских граждан увеличилось за 41 год на 1 миллион человек (с 4063 тыс. до 4937 тыс.). Однако это увеличение было связано не столько с результатом законотворчества Августа, сколько с прекращением гражданских войн и возвращением к нормальной жизни (Чаплыгина, 1995: 110).

Отсутствие четких и действенных механизмов регулирования брачно-семейных отношений и контроля за исполнением брачных законов приводило к тому, что государство при их осуществлении вынуждено было опираться на самые примитивные и грубые методы. Несмотря на то, что законоположения о праве трех детей в основе своей имели положительные причины, они стали нарушаться фактически уже в правление Августа. Введение штрафов, вплоть до конфискации имущества, и выплата значительных наград доносчикам способствовали распространению доносительства. Причем, если первоначально государство хотя бы формально применяло эти карательные меры по отношению к нарушителям закона, то затем, по мере все увеличивавшихся финансовых затруднений империи, брачные законы все больше стали использоваться в целях пополнения казны новыми лоходами. По сообщению Тацита, в результате законов Папия и Поппея «появились надзиратели, чтобы римский народ наследовал как общий отец после отказавшихся от преимуществ отцовства выморочное имущество. Но эти надзиратели заходили гораздо дальше, накидывались на Рим, на Италию, на все, где только были римские граждане, и довели многих до разорения» (Тацит, 2001: 117-129). Выигрывало государство и от конфискации имущества осужденных за прелюбодеяния. При помощи процессов по обвинению устранялись неугодные политические противники, что приводило к вымиранию старой римской знати. В результате применения этих законов Августа в первой четверти I в. н. э. полностью были уничтожены видные сенаторские роды Клавдиев, Сципионов, Семпрониев Гракхов (Крист, 1997: 111) и др.

Противоречивый характер брачно-семейного законодательства Августа, которое, с одной стороны, было направлено на укрепление традиционной римской семьи, но в то же время, с другой, использовалось государством в качестве средства для расправы с противниками режима, позволяет считать, что оно, очевидно, могло преследовать и более широкие цели, нежели борьба с негативными процессами развития римского общества.

В отечественной историографии брачные законы Августа рассматриваются, в основном, в общих трудах, посвященных реставрационной политике Августа. Большинство советских историков в той или иной степени связывали брачно-семейное законодательство императора с попытками на- 
Научные труды Московского гуманитарного университета 2019 № 2

рождающейся монархии остановить процесс вырождения старой римской знати и увеличить ее численность (Сергеев, 1938: 403-404; Ковалев, 1986: 483-485; Брейкин, 1992: 91). По мнению других, забота о росте населения и увеличении числа будущих солдат имела значение скорее как официальный мотив брачного законодательства, чем как истинная его причина. Главное же заключалось в том, что семья была важнейшей ячейкой римского рабовладельческого общества, а потому брачное законодательство находилось в тесной связи с политикой укрепления рабовладения (Машкин, 1949: 418, 425-426; Штаерман, 1956: 602). Наряду с этим, ряд историков пытались соединить оба вышеназванных подхода, указав, что программа Августа по возрождению старинных нравов и оздоровлению семьи являлась органичной частью политики «восстановления республики» и занимала важное, если не ключевое, место в создававшейся системе (Межерицкий, 1994: 223).

Представляется, что брачно-семейное законодательство было неразрывно связано, прежде всего, с изменением роли и места высших сословий в системе нарождающейся монархии Августа. В условиях принципата, когда знать становится главной опорой монархии, высшие сословия все больше рассматривались режимом в качестве служилого населения, предназначение которого заключалось во всесторонней поддержке монархии и обслуживании созданной государственной системы, а потому их личная жизнь должна была подчиняться государственным интересам. Вследствие этого государство было заинтересовано не только в лояльности высших сословий по отношению к новому режиму, но и последовательно стремилось к регламентации всех сторон жизни римского общества, в том числе и посредством установления контроля над личной жизнью граждан. Поэтому можно полагать, что семейное законодательство Августа преследовало двоякую цель. С одной стороны, государство, таким образом, пыталось навести порядок в области семьи и брака, путем возрождения староримских ценностей укрепить римскую семью. С другой - с помощью брачных законов имперские власти стремились поставить под свой контроль личную жизнь граждан, укрепить зависимость высших сословий от государства, сделать их послушными проводниками своей политики, исключить возможность возникновения в рядах знати оппозиции правящему режиму.

Активное проведение в жизнь этой политики, потребовавшее от государства всего напряжения сил, вызвало крайнее недовольство и сопротивление римской знати, тяжело переживавшей вмешательство в свою личную жизнь. Угроза утраты поддержки высших сословий в какой-то степени объясняет ту непоследовательность и противоречивость семейной политики Августа, который при ее проведении был вынужден постоянно лавировать между стремлением укрепить свое влияние на римское общество и поддер- 
жанием союза со знатью, являвшегося необходимым условием сохранения власти принцепса. В итоге, брачно-семейное законодательство Августа оказалось не только не в состоянии избавить общество от моральной деградации, но и объективно способствовало дальнейшему обострению кризиса римской семьи. Оно еще больше разрушило в ней традиционные отношения, которые так настойчиво стремился возродить в своей политике Август, так как подменяло власть главы семьи властью государства, ибо карать своих домочадцев теперь должен был уже не муж, а суд. Этот переход прежних функций главы семьи к государству, вызванный, как и общий кризис римского общества, кризисом полисной модели римского государства и традиционных для нее брачно-семейных отношений, способствовал дальнейшему разрыву прежних отношений между членами патриархальной римской семьи, а вслед за ним неизбежно вел и к еще большему упадку моральных устоев древнеримского общества. Расширение вмешательства государства в личную жизнь римлян при ближайших преемниках Августа еще больше ухудшило ситуацию в области брачно-семейных отношений.

\section{СПИСОК ЛИТЕРАТУРЫ}

Брейкин, О. В. (1992) Мораль Древнего Рима (VIII-I вв. до н. э.). Саранск: Изд-во Мордовского университета. 104 с.

Бэлсдон, Д. П. (2016) Женщины древнего Рима / пер. с англ. М.: ЗАЩ Центрполиграф. 319 с.

Веллей Патеркул (1996) Римская история // Малые римские историки. Веллей Патеркул. Римская история. Анней флор. Две книги Римских войн. Луций Ампелий. Памятная книжица / пер. с лат. А. И. Немировского М.: Ладомир. 387с.

Вергилий (1971) Буколики. Георгики. Энеида / пер. с лат. М.: Художественная литература. 462 с.

Гребенюк, А. В. (1994) Цивилизации античного мира и средневековой Европы. Методологические очерки. М.: Высшая школа. 301 с.

Гораций Квинт Флакк (1936) Юбилейный гимн // Полное собрание сочинений. М.: Акаdemia. С. 173-179.

Дигесты Юстиниана (2005) / пер. с лат. М.: Статут. Т. 7. Полутом 2. 564 с.

Дмитренко, В. (2004) Властители Рима. Время правления Октавиана Августа и династии Юлиев-Клавдиев. М.: 000 «Изд-во АСТ»; Харьков: «Фолио». $781 \mathrm{c.}$

Домиций Ульпиан (1998) Фрагменты // Юлий Павел. Пять книг сентенций к сыну. Фрагменты Домиция Ульпиана / пер. с лат. Е. М. Штаерман; отв. ред. и сост. Л. Л. Кофанов. М.: Зерцало. 285 с. 
Егер, О. (1997) Всемирная история. СПб.: Специальная литература. Т. I. Древний мир. 821 с.

Кассий Дион Коккейан (2014) Римская история. Книги LI — LXIII / пер. с древнегреч. А. В. Махлаюка, К. В. Маркова, Е. А. Молева, Н. Ю. Сивкиной, С. К. Сизова, В. М. Строгецкого. СПб.: Нестор-История. 680 с.

Крист, К. (1997) История времен римских императоров от Августа до Константина. Ростов н/Д. : Феникс. Т. І. 573 с.

Ковалев, С. И. (1986) История Рима. Л.: Издательство Ленинградского университета. 744 с.

Кузищин, В. И. (2000) Ранняя римская империя // История Древнего Рима М. : Высшая школа. С. 190-308.

Машкин, Н. А. (1949) Принципат Августа: происхождение и социальная сущность. М. ; Л. : Изд-во АН СССР. 685 с.

Межерицкий, Я. Ю. (1994) «Республиканская монархия»: метаморфозы идеологии и политики императора Августа. М.; Калуга: Изд-во КГПУ. 442 с.

Новицкий, И. Б. (1998) Римское право. М.: Теис. 248 с.

Публий Овидий Назон (1990) Искусство любви / пер. с лат. М. Л. Гаспарова. М.: Изд-во политической литературы. 319 с.

Юлий Павел (1998). Пять книг сентенций к сыну. Фрагменты Домиция Ульпиана / пер. с лат. Е. М. Штаерман. М.: Зерцало. 285 с.

Гай Светоний Транквилл (1990) Жизнь двенадцати цезарей / Пер. с лат. М. Л. Гаспарова. М.: Художественная литература. 255 с.

Сергеев, В. С. (1938) Очерки по истории Древнего Рима. М.: Соцэкгиз. T. II. 464 c.

Публий Корнелий Тацит (2001) Анналы. Малые произведения. История / пер. с лат. М.: 000 «Издательство АСТ»; «Ладомир». 992 с.

Токарев, А. В. (2004) 0 целях семейного законодательства Октавиана Августа // Вісник Харківського національного униівеситету. Сер. Історія. Вип. 36. С. 222-231.

Чаплыгина, Н. А. (1995) Римская женщина в правление Августа // Женщина в античном мире : сб. статей. М.: Наука. С. 104-130.

Ферреро, Г. (1998) Величие и падение Рима. М.: Наука, Ювента. Т. 4. Республика Августа. 159 с.

Шифман, И. Ш. (1990) Цезарь Август. Л.: Наука. 200 с.

Штаерман, Е. М. (1956) Ранняя Римская империя // Всемирная история: в 10 т. М. : Государственное издательство политической литературы Т. II. С. 597-636.

Юлий Павел (1998) Пять книг сентенций к сыну. Фрагменты Домиция Ульпиана / пер. с лат. Е. М. Штаерман; отв. ред. и сост. Л. Л. Кофанов. М.: Зерцало. 285 с. 

349.

Betzig, L. (1992) Roman polygyny // Ethology and sociobiology. № 13. 309-

Csillag, P. (1976) The Augustan laws of family relation. Budapest: Akademiai Kiado. 275 p.

Galinsky, K. (1981) Augustus Legislation on moralis and marriage // Philologus. Bd. 125. Pp. 126-144.

Hopkins, K (1983) Death and Renewal, Cambridge Cambridge University Press. 110 p.

Cambridge Ancient History (2008). Cambridge: Cambridge University Press. Vol. 10. 1137 p.

Levy, M. A. (1951) Il tempo di Augusto. Florence. Florence: La Nuova Italia. $506 \mathrm{p}$.

Mcnally, M. (2011) Teutoburg forest. 9 AD. The destruction of Varus and his legions. West Vay, Botley; Oxford. 100 p.

Treggiari, S (1991) Roman Marriage. Iusti Coniuges From the Time of Cicero to the time of Ulpian. Oxford. Cldrendon. $578 \mathrm{p}$.

Дата поступления: 13.03.2019 г.

Инков Александр Александрович - кандидат исторических наук, доцент, доцент кафедры истории Московского гуманитарного университета. Адрес: 111395, Россия, г. Москва, ул. Юности, д. 5. Тел.: + 7 (499) 374-55-81. Эл. адрес: historymosgy@mail.ru

Inkov Aleksandr Aleksandrovich, Candidate of History, Associate Professor, Associate Professor, Department of History, Moscow University for the Humani_ ties. Postal address: 5, Yunosti St., Moscow, Russian Federation, 111395. Tel.: +7 (499) 374-55-81. E-mail: historymosgy@mail.ru

\section{Для цитирования:}

Инков А. А. Брачные законы как инструмент укрепления Римского государства в правление Октавиана Августа [Электронный ресурс] // Научные труды Московского гуманитарного университета. 2019. №2. URL: http://journals.mosgu.ru/trudy/article/view/958 (дата обращения: дд.мм.гг.). DOI: 10.17805/trudy.2019.2.1 